\title{
Expression of prostanoid receptor genes in baboon chorion and decidua during pregnancy and parturition
}

\author{
G C S Smith, W X Wu and P W Nathanielsz \\ Laboratory for Pregnancy and Newborn Research, Department of Physiology, College of Veterinary Medicine, Cornell University, Ithaca, New York 14853, \\ USA \\ (Requests for offprints should be addressed to G C S Smith, University of Glasgow, Department of Obstetrics and Gynaecology, The Queen Mother's \\ Hospital, Yorkhill, Glasgow G3 8SH, UK; Email: gcs4@,cornell.edu)
}

\begin{abstract}
The aim of this study was to determine whether expression of prostanoid receptor genes varied with gestational age or labour in the decidua and chorion of baboons. Tissues were obtained at the time of Caesarean hysterectomy in 15 baboons, 10 prior to the onset of labour in the last third of pregnancy and 5 in spontaneous labour at term. Expression of prostanoid receptor genes was determined using Northern blot analysis and the level of expression was related to each of three housekeeping genes. Expression of the genes encoding the $\mathrm{EP}_{1}$ and $\mathrm{FP}$ receptor in decidua and the $\mathrm{EP}_{4}$ receptor in chorion was
\end{abstract}

lower with advancing gestational age. Expression of the $\mathrm{EP}_{2}$ receptor gene was lower in labour in decidua, whereas expression of the IP receptor gene was higher in labour in both decidua (twofold) and chorion (fourfold). It is concluded that there is a complex pattern of change in expression of prostanoid receptor genes in chorion and decidua with advancing gestational age and in association with labour. It seems likely that direct effects of prostaglandins on the choriodecidua may have an important role in parturition in the primate.

Journal of Endocrinology (2001) 168, 263-272

\section{Introduction}

The fetal membranes and decidua are thought to have a key role in the control of parturition in the human and non-human primate. In analyses of cases of preterm labour, approximately $30-40 \%$ of births are associated with prelabour rupture of the membranes (Creasy \& Iams 1999). Furthermore, the membranes have an important paracrine role in the control of myometrial contractility, both in spontaneous term labour (Challis et al. 1997) and in preterm labour secondary to intra-uterine infection (French \& McGregor 1996). The decidua is also thought to have an important paracrine role in the control of the myometrium (Casey \& MacDonald 1988).

Currently, most models for the role of prostaglandins (PGs) in the fetal membranes and decidua consider the membranes as a source of either PG biosynthesis or a site of PG catabolism (Challis et al. 1997). Furthermore, any effects of PGs from the fetal membranes and decidua are thought to be paracrine, mediated through changes in myometrial contraction (French \& McGregor 1996). The genes encoding a family of at least eight distinct prostanoid receptors have been cloned and sequenced and match closely with pharmacologically defined receptor types and sub-types (Coleman et al. 1994). We recently demonstrated a complex pattern of expression of these genes in the chorion and decidua of pregnant baboons (Smith et al. 1998), which suggests that PGs synthesised in the membranes and decidua may also have autocrine effects.

We hypothesise that altered sensitivity to prostaglandins mediated by variation in the population of prostanoid receptors expressed in critical intra-uterine tissues may have a role in the control of parturition in primates. Characteristically, genes encoding signal transduction proteins which have a role in labour are expressed at higher levels in tissues (both myometrial and non-myometrial) from animals which are in labour, and there are many examples of such phenomena (Tabb \& Garfield 1992, Wu et al. 1996, Ou et al. 1997, Slater et al. 1999, Wu et al. 1999). As an initial test of our hypothesis that PG receptors have a direct role in the control of the chorion and decidua around labour, we sought to determine whether expression of these genes varied according to gestational age and whether the animal was in labour or not in labour at the time the tissue was obtained.

\section{Materials and Methods}

Care and use of animals

Animal care and surgical procedures have been described in detail previously (Morgan et al. 1992). Pregnant 
baboons were obtained from the Southwest Foundation for Biomedical Research, San Antonio, TX, USA. They had been harem mated and gestational age was confirmed by early ultrasound. Total Caesarean hysterectomy was performed under general anaesthesia (ketamine induction, halothane maintenance).

At the time of surgery, 10 animals were not in labour and were in the last third of pregnancy at the following days gestational age (dGA): 121, 128, 141, 153, 159, 162, $162,177,177,180$ (term $=180-185$ days). The cervix was un-effaced and closed in all of these animals. Uterine electromyogram leads had been sited in three of these animals going close to term (delivered at 177, 177 and 180 dGA). Analysis of electromyogram (EMG) traces of the $48 \mathrm{~h}$ preceding surgery revealed no contraction activity. No drugs of any form had been administered to any of the animals in the two weeks preceding surgery. Hysterectomies prior to the onset of labour were performed over a period of two years. In some analyses, samples were not available for all animals from this pool. Caesarean hysterectomy was also performed on five animals in spontaneous labour. Of these, four had EMG electrodes sited. Labour was diagnosed by cervical dilatation and effacement. These animals had a baseline cervical examination at the time of their first EMG contraction activity and a repeat cervical examination was performed when they had a sustained switch from contractures to contractions (>30 min). Hysterectomy was performed on the basis of cervical changes. The gestational ages at hysterectomy were 164, 184, 191, 193 days. The cervical dilations for these animals were $6 \mathrm{~cm}, 3 \mathrm{~cm}, 3 \mathrm{~cm}$ and $2 \mathrm{~cm}$ respectively (the cervix was closed in all four at the baseline examination). In a fifth animal without EMG electrodes, Caesarean section was performed at 172 dGA and at the time of the Caesarean section it was found that the cervix was $4 \mathrm{~cm}$ dilated and fully effaced and a hysterectomy was performed.

The chorion and amnion were separated and flash frozen in liquid nitrogen. Decidua were removed following separation of the fetal membranes and were flash frozen. All procedures were approved by the Cornell University Institutional Animal Care and Use Committee and the facilities were approved by the American Association for the Accreditation of Laboratory Animal Care.

\section{Northern analysis}

Polyadenylated ribonucleic acid (RNA) was extracted from frozen tissue by oligo-thymidylic acid-cellulose affinity chromatography using a commercial kit (Fast Track $2 \cdot 0$, Invitrogen, San Diego, CA, USA). Samples of polyadenylated RNA ( 2 or $4 \mu \mathrm{g}$ ) were denatured in $17 \cdot 4 \%$ ( $\mathrm{vol} / \mathrm{vol})$ formaldehyde, $50 \%$ (vol/vol) freshly deionised formamide, $20 \mathrm{mM}$ MOPS (3-(N-morpholino) propanesulfonic acid), $5 \mathrm{mM}$ sodium acetate and $1 \mathrm{mM}$
EDTA, $\mathrm{pH} 7 \cdot 0$, for $5 \mathrm{~min}$ at $65{ }^{\circ} \mathrm{C}$ and separated by electrophoresis on a $1.4 \%$ (wt/vol) agarose- $0.66 \mathrm{M}$ formaldehyde gel. The gel was visualised under ultraviolet trans-illumination and photographed to determine the distance of migration of a series of standard size RNA markers (Gibco, MD, USA). The RNA was transferred onto a nylon membrane (Gene Screen plus, NEN Dupont, MA, USA) by capillary blotting for $24 \mathrm{~h}$ in $10 \times \operatorname{SSC}(1 \times$ SSC is $0 \cdot 15 \mathrm{M} \mathrm{NaCl}$ and $0 \cdot 015 \mathrm{M}$ sodium citrate, $\mathrm{pH} 7 \cdot 0)$. Pre-hybridisation $(>1 \mathrm{~h})$ and hybridisation $(>18 \mathrm{~h})$ were carried out in hybridisation bottles in an oven at $65^{\circ} \mathrm{C}$ when using riboprobes and at $45^{\circ} \mathrm{C}$ in sealed bags when a cDNA probe was used. A commercial $50 \%$ formamide based hybridisation buffer was employed (Northern Max or UltraHyb, Ambion, Austin, TX, USA). The probe concentration was approximately $1 \times 10^{6}$ counts per min per $\mathrm{ml}$ hybridisation buffer. Membranes were washed twice for five min in $2 \times$ SSC and $0.1 \%$ SDS at $65{ }^{\circ} \mathrm{C}$ and twice for one hour in $0.1 \times$ SSC and $0.1 \%$ SDS at $65{ }^{\circ} \mathrm{C}$ when riboprobes were employed and were washed in the same buffers but at $45^{\circ} \mathrm{C}$ when cDNA probes were employed. Kodak X-Omat film was exposed to the membrane with an intensifying screen at $-80{ }^{\circ} \mathrm{C}$. After probing for the receptor gene of interest, membranes were stripped (see below) and re-probed for housekeeping genes (see below).

\section{Synthesis of probes}

The $\mathrm{EP}_{1}, \mathrm{EP}_{2}, \mathrm{EP}_{3}, \mathrm{EP}_{4}, \mathrm{FP}, \mathrm{IP}$ and $\mathrm{DP}$ prostanoid receptor complementary deoxyribonucleic acids (cDNAs) had been cloned into either the pcDNA3 or pcDNAIamp vectors (both Invitrogen), which include promoters for phage polymerases SP-6 and T-7. The plasmid was linearized by an appropriate restriction enzyme and antisense riboprobes were synthesised using a commercial kit (StripEZ RNA, Ambion) labelled with $\left[\alpha-{ }^{32}\right.$ P]UTP $(800$ $\mathrm{Ci} / \mathrm{mmol}$ ) (NEN Dupont). Template DNA was removed by addition of $2 \mathrm{U}$ RNase-free DNase and incubation for $15 \mathrm{~min}$ at $37^{\circ} \mathrm{C}$. cDNA probes were used where riboprobes could not be synthesised and the inserts were labelled with $\left[\alpha-{ }^{32} \mathrm{P}\right]$ deoxy-CTP $(3000 \mathrm{Ci} / \mathrm{mmol})$ using the random priming method (StripEZ DNA, Ambion) to specific activities of approximately $1 \times 10^{9}$ c.p.m. $/ \mu \mathrm{g}$. Both DNA and RNA probes was separated from unincorporated nucleotide using a Sephadex spin column (Probe Quant G-50, Pharmacia Amersham, NJ, USA) and quantified. Probes were stripped from membranes using the manufacturer's protocol (Strip EZ RNA and Strip EZ DNA, both Ambion) and membranes were consecutively stripped and re-probed to each of three housekeeping genes.

The human $\mathrm{EP}_{2}$ receptor $\mathrm{cDNA}$ was obtained from Dr D F Woodward of Allergen, Irvine, CA, USA. The human prostanoid receptor $\mathrm{DP}, \mathrm{EP}_{3}, \mathrm{EP}_{4}$, IP, and $\mathrm{FP}$ cDNAs were obtained from Dr M Abramovitz of Merck 
A. B.

$\begin{array}{lllllllllllllll}1 & 2 & 3 & 4 & 5 & 6 & 7 & 8 & 9 & 10 & 11 & 12 & 13 & 14 & 15\end{array}$

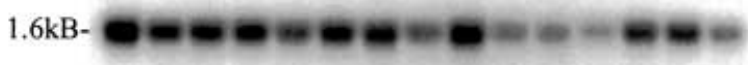

EP1 receptor

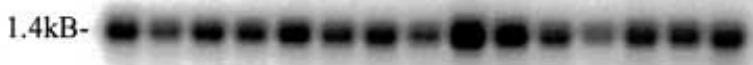
GAPDH

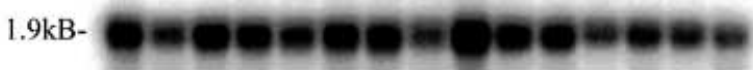

Beta-actin

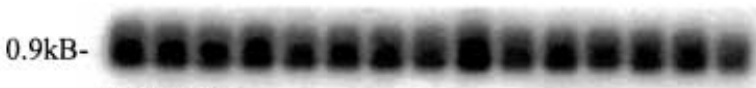

Cyclophilin

C.

$\begin{array}{llllllllllllll}1 & 2 & 3 & 4 & 5 & 6 & 7 & 8 & 9 & 10 & 11 & 12 & 13 & 14\end{array}$

$7.7 \mathrm{kB}-$

$5.5 \mathrm{kB}-$

$2.6 \mathrm{kB}-$

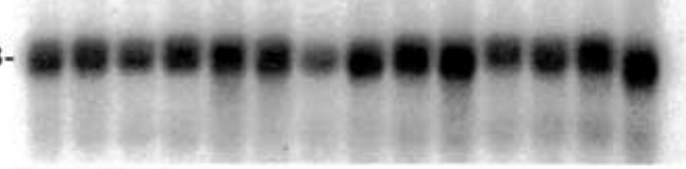

\section{EP3 receptor}

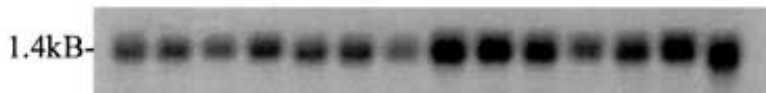

GAPDH

$1.9 \mathrm{kB}-$

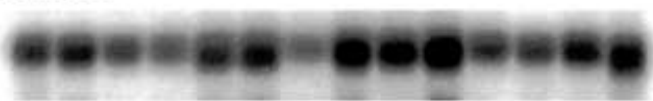

Beta-actin

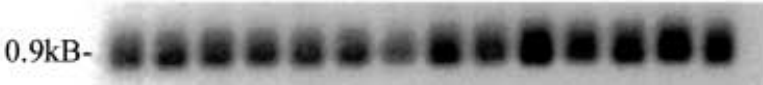

Cyclophilin $\begin{array}{llllllllllllll}1 & 2 & 3 & 4 & 5 & 6 & 7 & 8 & 9 & 10 & 11 & 12 & 13 & 14\end{array}$

$2.5 \mathrm{kB}-$

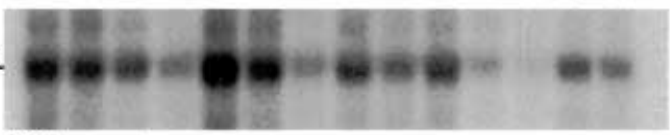

EP2 receptor

$1.4 \mathrm{kB}-$

GAPDH

$1.9 \mathrm{kB}-$

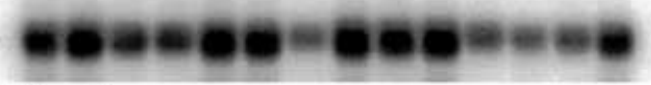

Beta-actin

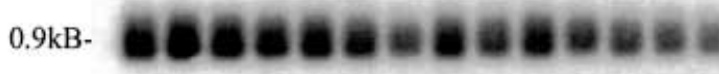

Cyclophilin

D.

$\begin{array}{llllllllllllll}1 & 2 & 3 & 4 & 5 & 6 & 7 & 8 & 9 & 10 & 11 & 12 & 13 & 14\end{array}$

$3.3 \mathrm{kB}-$

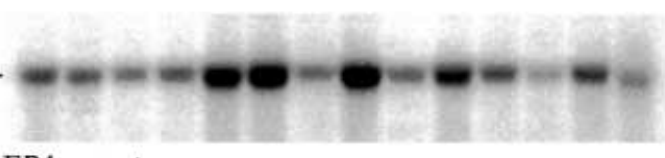

EP4 receptor

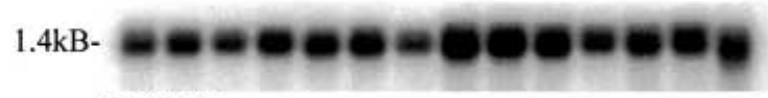

\section{GAPDH}

$1.9 \mathrm{kB}-$

Beta-actin

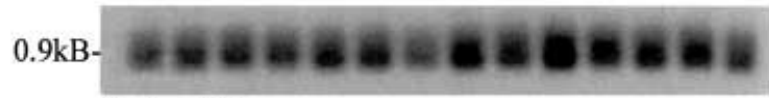

Cyclophilin

Figure 1 Northern blot of mRNA from decidua (either 2 or $4 \mu$ g each lane, same quantity loaded in each lane in a given blot) probed for (A) $\mathrm{EP}_{1}$ receptor gene, (B) $\mathrm{EP}_{2}$ receptor gene, (C) $\mathrm{EP}_{3}$ receptor gene and (D) $\mathrm{EP}_{4}$ receptor gene. All membranes were consecutively stripped and re-probed for housekeeping genes. The estimated size of transcripts is given in kilobases (kB). A: lanes 1-10 not in labour, lanes 11-15 in labour; B, C and D: lanes 1-9 not in labour, lanes 10-14 in labour. 
A. B.

$\begin{array}{lllllllllllllll}1 & 2 & 3 & 4 & 5 & 6 & 7 & 8 & 9 & 10 & 11 & 12 & 13 & 14\end{array}$
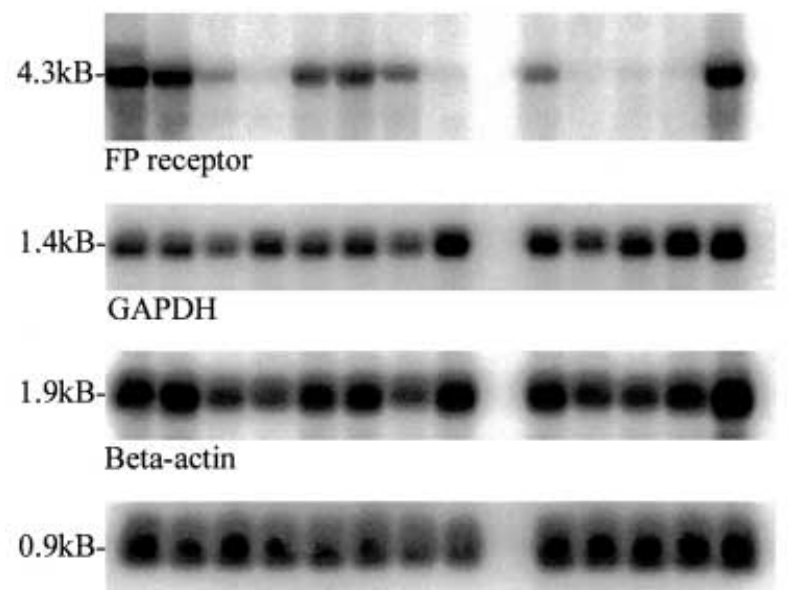

Cyclophilin $\begin{array}{lllllllllllllll}1 & 2 & 3 & 4 & 5 & 6 & 7 & 8 & 9 & 10 & 11 & 12 & 13 & 14\end{array}$

$2.0 \mathrm{kB}-$

\section{$=$}

IP receptor

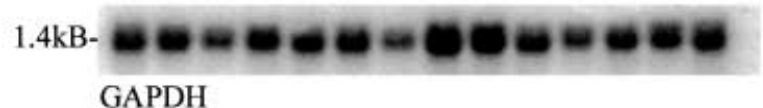

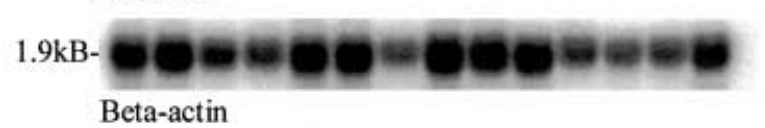

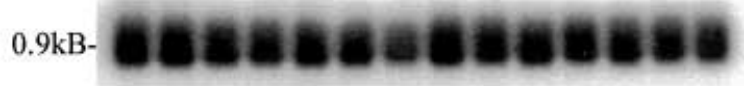

Cyclophilin

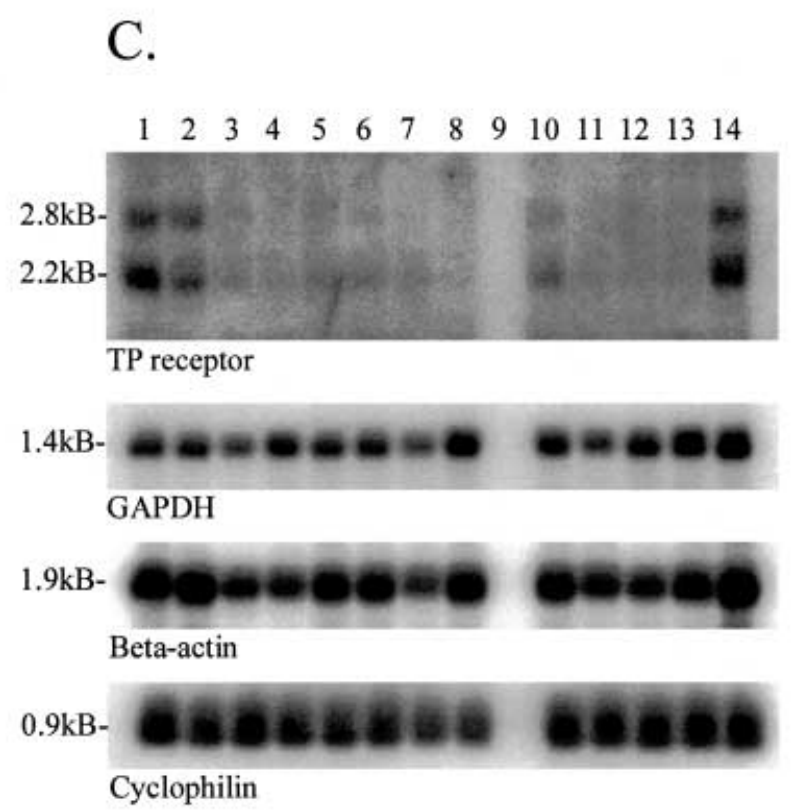

Figure 2 Northern blot of mRNA from decidua (either 2 or $4 \mu \mathrm{g}$ each lane, same quantity loaded in each lane in a given blot) probed for (A) FP receptor gene, (B) IP receptor gene and (C) TP receptor gene. All membranes were consecutively stripped and re-probed for housekeeping genes. The estimated size of transcripts is given in kilobases (kB). A and C: lanes 1-8 not in labour, lanes 10-14 in labour; B: lanes 1-9 not in labour, lanes 10-14 in labour. Lane 9 was empty in A and C.

Frosst, Quebec, Canada. The human TP receptor cDNA was obtained from Oxford Biomedical (MI, USA) and the mouse $\mathrm{EP}_{1}$ receptor $\mathrm{cDNA}$ was obtained from $\mathrm{Dr}$ Y Sugimoto (Kyoto University, Japan). The plasmids (all
TRIscript, Ambion) containing the glyceraldehyde-3phosphate dehydrogenase (GAPDH), beta-actin and cyclophilin cDNAs with RNA polymerase promoters were purchased from Ambion. 
A.

$\begin{array}{llllllllllll}2 & 3 & 4 & 5 & 6 & 7 & 8 & 9 & 10 & 11 & 12 & 13\end{array}$

$1.6 \mathrm{kB}-$

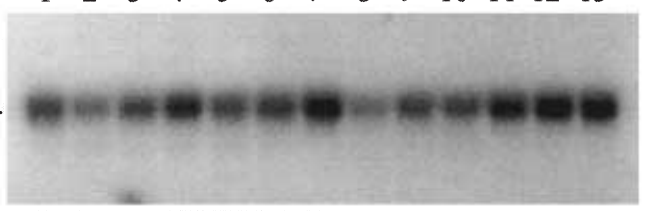

EP1 receptor

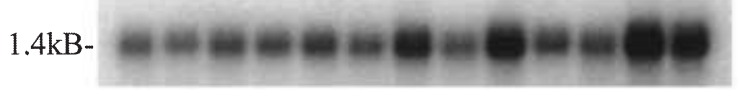

GAPDH

$1.9 \mathrm{kB}-$

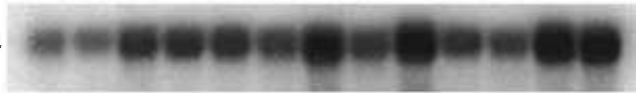

Beta-actin

$0.9 \mathrm{kB}-$

Cyclophilin

C.

$\begin{array}{lllllllllllll}1 & 2 & 3 & 4 & 5 & 6 & 7 & 8 & 9 & 10 & 11 & 12 & 13\end{array}$

$7.7 \mathrm{kB}-$

$5.5 \mathrm{kB}-$

$2.6 \mathrm{kB}-$

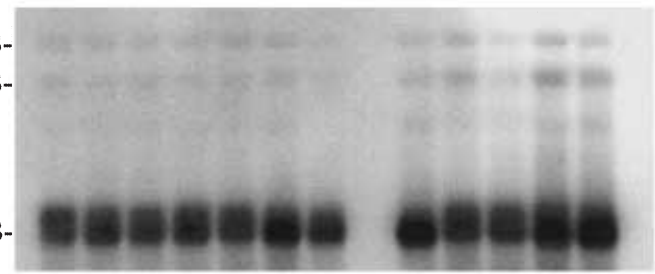

EP3 receptor

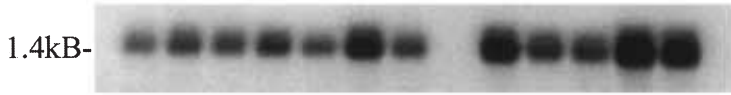

GAPDH

$1.9 \mathrm{kB}-$

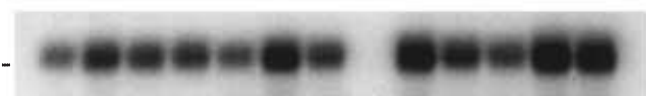

Beta-actin

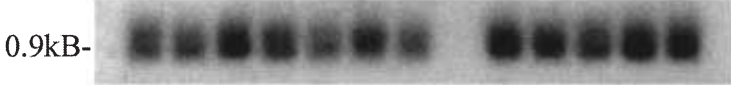

Cyclophilin
B.

$\begin{array}{lllllllllllll}1 & 2 & 3 & 4 & 5 & 6 & 7 & 8 & 9 & 10 & 11 & 12 & 13\end{array}$

$2.5 \mathrm{kB}-$

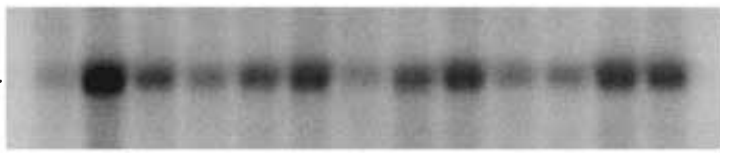

EP2 receptor

$1.4 \mathrm{kB}-$

\section{GAPDH}

$1.9 \mathrm{kB}-$

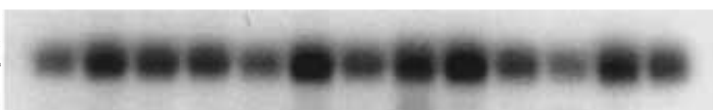

\section{Beta-actin}

D.

$\begin{array}{llllllllllllll}1 & 2 & 3 & 4 & 5 & 6 & 7 & 8 & 9 & 10 & 11 & 12 & 13\end{array}$

$3.3 \mathrm{kB}-$

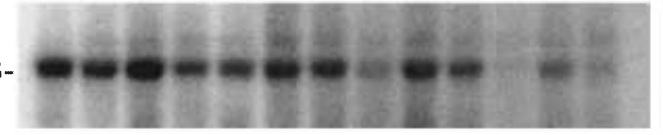

EP4 receptor

$1.4 \mathrm{kB}-$

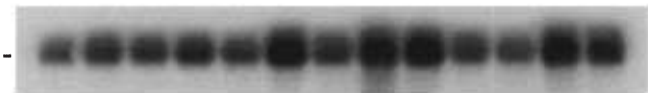

GAPDH

$1.9 \mathrm{kB}-$

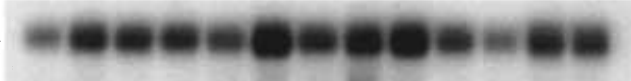

Beta-actin

$0.9 \mathrm{kB}-$

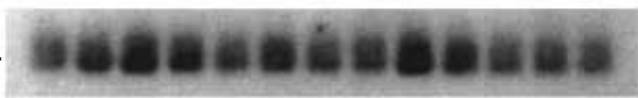

Cyclophilin

Figure 3 Northern blot of mRNA from chorion (either 2 or $4 \mu \mathrm{g}$ each lane, same quantity loaded in each lane in a given blot) probed for (A) $\mathrm{EP}_{1}$ receptor gene, $(\mathrm{B}) \mathrm{EP}_{2}$ receptor gene, $(C) \mathrm{EP}_{3}$ receptor gene and (D) $\mathrm{EP}_{4}$ receptor gene. All membranes were consecutively stripped and re-probed for housekeeping genes. The estimated size of transcripts is given in kilobases (kB). A, B and D: lanes 1-8 not in labour, lanes $9-13$ in labour; C: lanes 1-7 not in labour, lanes 9-13 in labour. Lane 8 was empty in C.

\section{Statistical analysis}

The estimated size of transcripts was calculated by fitting a curve (using Graph Pad Prism, version 3.0, Graph Pad Software, San Diego, CA, USA) to the graph of distance of migration plotted against molecular weight of the markers. The size of autoradiographic signals was quantified using densitometry. All bands which were clearly greater than background were analysed densitometrically. The expression of a given prostanoid receptor gene was 
A.

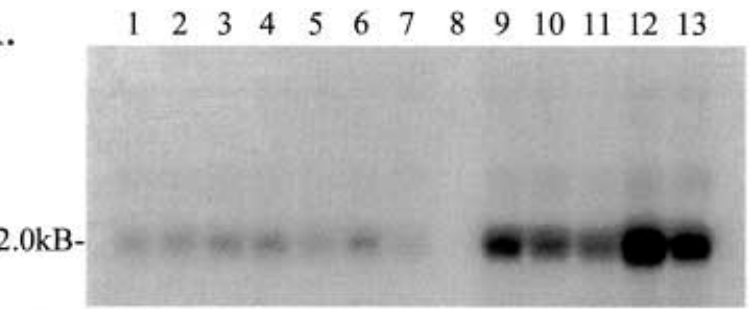

IP receptor

$1.4 \mathrm{kB}-$

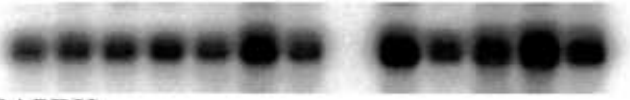

GAPDH

$1.9 \mathrm{kB}-$

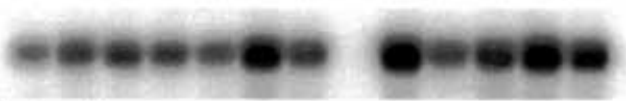

Beta-actin

$0.9 \mathrm{kB}-$

Cyclophilin

B.

$\begin{array}{lllllllllllll}1 & 2 & 3 & 4 & 5 & 6 & 7 & 8 & 9 & 10 & 11 & 12 & 13\end{array}$

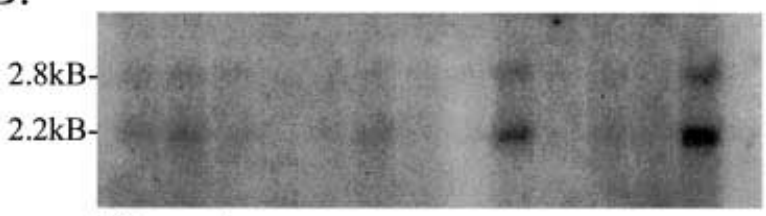

TP receptor

$1.4 \mathrm{kB}-$

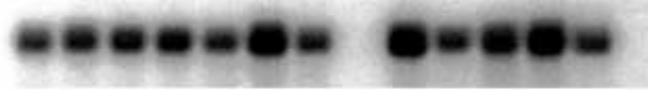

\section{GAPDH}

$1.9 \mathrm{kB}-$

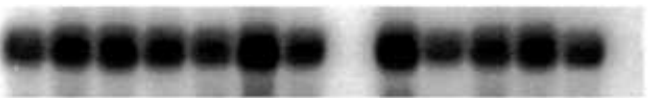

Beta-actin

$0.9 \mathrm{kB}-$

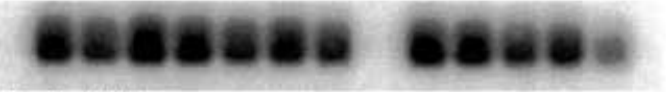

Cyclophilin

Figure 4 Northern blot of mRNA from chorion (either 2 or $4 \mu \mathrm{g}$ each lane, same quantity loaded in each lane in a given blot) probed for (A) IP receptor gene and (B) TP receptor gene. All membranes were consecutively stripped and re-probed for housekeeping genes. The estimated size of transcripts is given in kilobases (kB). Both blots: lanes 1-7 not in labour, lanes 9-13 in labour. Lane 8 was empty in both plots.

expressed as a ratio to each of three housekeeping genes: GAPDH, beta-actin and cyclophilin. Comparison of two means was made by Student's $t$-test. Correlation was determined using simple linear regression and Spearman's rho. Comparison of means adjusted for gestational age was performed using analysis of covariance and the comparison normalised to $180 \mathrm{dGA}$. Statistical analysis was performed using Stata College Station, TX, USA, version 6.0 for Windows. Statistical significance was assumed at the 5\% level.

\section{Results}

Clear signals of similar molecular weight to the cloned human prostanoid receptors genes were detected in decidua to probes for the $\mathrm{EP}_{1}, \mathrm{EP}_{2}, \mathrm{EP}_{3}, \mathrm{EP}_{4}, \mathrm{FP}$, and IP receptors (Figs 1 and 2). No clear signal above background could be detected using an antisense riboprobe for the human DP receptor. Clear signals of similar molecular weight to the cloned human prostanoid receptors genes were detected in chorion to probes for the $\mathrm{EP}_{1}, \mathrm{EP}_{2}, \mathrm{EP}_{3}$, $\mathrm{EP}_{4}$, and IP receptors (Figs 3 and 4). No clear signal above background could be detected using antisense riboprobes for the human DP or FP receptor genes. Weak signals could be detected in both tissues to a TP receptor probe (Figs 2 and 4). However, the signal to noise ratio for the TP receptor gene transcript was too low in both tissues for meaningful quantitative analysis.

When related to the signal for beta-actin, there was a statistically significant negative correlation between the level of expression of the $\mathrm{EP}_{1}$ and $\mathrm{FP}$ receptor genes in decidua and $\mathrm{EP}_{4}$ expression in the chorion and the gestational age at the time of hysterectomy among animals which were not in labour (Fig. 5). There were no other significant relationships between gene expression and gestational age in either tissue (all $P>0 \cdot 05$ ). Results of similar statistical significance were obtained when correlation was tested using Spearman's rho (data not shown).

Signals obtained from animals in labour and not in labour were related to beta-actin and compared. There was a significantly lower level of expression of the $\mathrm{EP}_{2}$ receptor gene in decidua among animals in labour (Fig. 6), but there was no significant difference comparing decidua from animals not in labour and those in labour for expression (all mean in arbitrary units (s.E.M.)) of the $\mathrm{EP}_{1}$ receptor gene $(0.47(0.04)$ vs $0.37(0.06)$ respectively, $P=0 \cdot 17)$, the $\mathrm{EP}_{3}$ receptor gene $(7.7 \mathrm{kB}$ transcript $=1.38$ $(0.09)$ vs $1.41(0 \cdot 11)$ respectively, $P=0.84 ; 5.5 \mathrm{kB}$ transcript $=1.66(0.11)$ vs $1.85(0.14)$ respectively, $P=0.32$; $2.6 \mathrm{kB}$ transcript $=1.25(0.09)$ vs $1.36(0.07)$ respectively, $P=0.42)$ and the $\mathrm{EP}_{4}$ receptor gene $(0.98(0.09)$ vs 1.18 $(0 \cdot 23)$ respectively, $P=0 \cdot 35)$. There was no significant difference comparing chorion from animals not in labour and those in labour for expression (all mean in arbitrary units (s.E.M.)) of the $\mathrm{EP}_{1}$ receptor gene (0.85 (0.08) vs $0 \cdot 89$ $(0 \cdot 15)$ respectively, $P=0 \cdot 79)$, the $\mathrm{EP}_{2}$ receptor gene $(0 \cdot 42$ $(0.09)$ vs $(0.43(0.08)$ respectively, $P=0.91)$, the $\mathrm{EP}_{3}$ receptor gene $(7.7 \mathrm{kB}$ transcript $=0.48(0.08)$ vs 0.36 $(0.04)$ respectively, $P=0.24 ; 5.5 \mathrm{kB}$ transcript $=0.47$ 
A. EP $_{1}$ Decidua

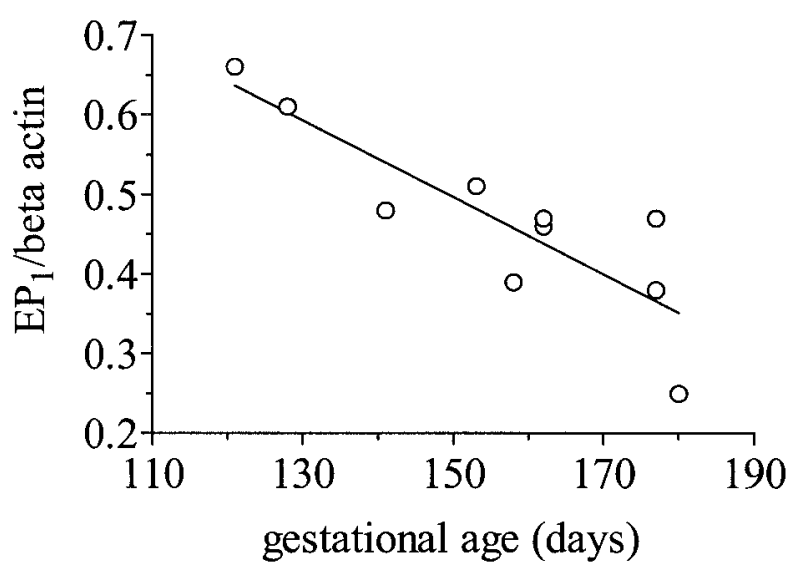

B. FP Decidua

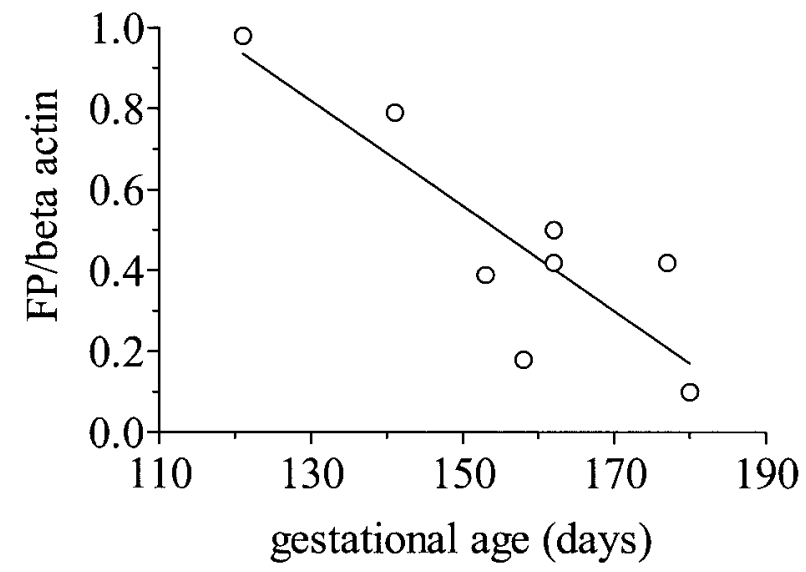

\section{C. $\mathbf{E P}_{4}$ Chorion}

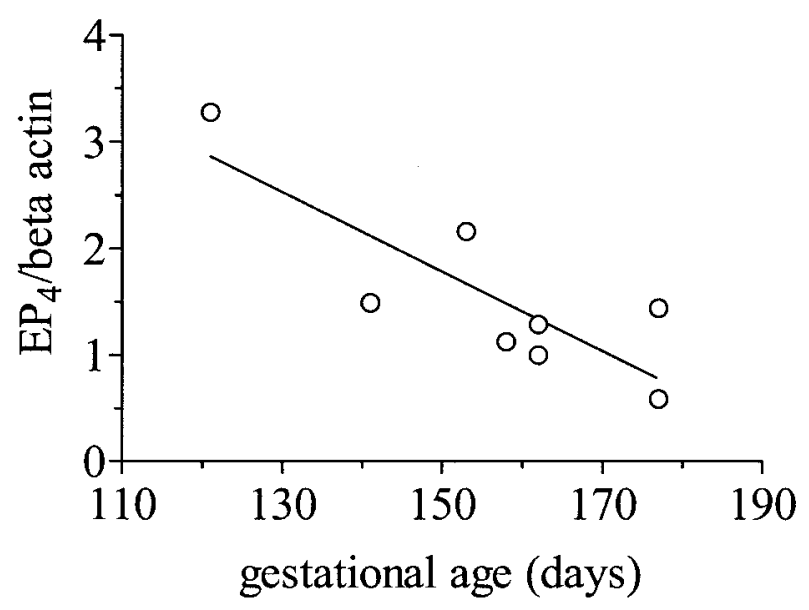

Figure 5 Simple linear regression of prostanoid receptor gene expression (expressed as a ratio to beta-actin) against gestational age among animals not in labour. (A) $\mathrm{EP}_{1}$ receptor gene in decidua $\left(r^{2}=0 \cdot 7, P=0 \cdot 002, n=10\right)$, (B) FP receptor gene in decidua $\left(r^{2}=0 \cdot 7, P=0 \cdot 008\right.$, $n=8),(C) \mathrm{EP}_{4}$ receptor gene in chorion $\left(r^{2}=0 \cdot 7, P=0 \cdot 01, n=8\right)$. Signals were quantified using densitometry and are expressed as a ratio (arbitrary units) to signal for beta-actin.

$(0 \cdot 07)$ vs $0.45(0 \cdot 04)$ respectively, $P=0.78 ; 2.6 \mathrm{kB}$ transcript $=2 \cdot 21 \quad(0 \cdot 28)$ vs $1.45 \quad(0 \cdot 13)$ respectively, $P=0.06)$, the $\mathrm{EP}_{4}$ receptor gene $(1.55(0.29)$ vs $0.95(0.14)$ respectively, $P=0 \cdot 16)$ or the FP receptor gene $(0 \cdot 47(0 \cdot 10)$ vs $0.26(0 \cdot 09)$ respectively, $P=0 \cdot 19)$. There was, however, a significantly higher level of IP receptor gene expression in both decidua and chorion obtained from animals in labour (Fig. 7).

For the signals which were observed to vary with gestational age $\left(\mathrm{EP}_{1}\right.$ and $\mathrm{FP}$ in decidua and $\mathrm{EP}_{4}$ in chorion) a further comparison was made of tissues obtained from animals in labour and animals not in labour, where the comparison was adjusted for gestational age using analysis of covariance. In all three cases there was still no significant change in levels of expression associated with labour after adjusting for the effect of gestational age $\left(\mathrm{EP}_{1}\right.$ decidua, $P=0.65 ; \mathrm{FP}$ decidua, $P=0.95 ; \mathrm{EP}_{4}$ chorion, $\left.P=0.65\right)$.

All the above comparisons were made expressing the level of the given gene as a ratio to beta-actin. Significant results were also observed when levels were expressed relative to one of the other housekeeping genes, with one exception. There was a negative correlation of borderline statistical significance between gestational age and $\mathrm{EP}_{1}$ expression in chorion relative to beta-actin $(P=0 \cdot 05)$. This association was not statistically significant when the $\mathrm{EP}_{1}$ signal was related either to GAPDH $(P=0.87)$ or to cyclophilin $(P=0 \cdot 11)$. 


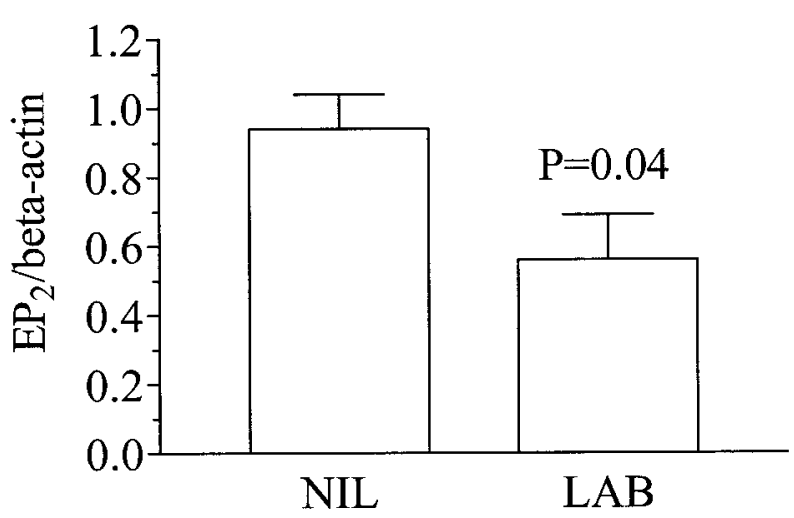

Figure 6 Densitometric analysis of expression of prostanoid $\mathrm{EP}_{2}$ receptor gene expression (expressed as a ratio to beta-actin) in decidua comparing labour $(\mathrm{LAB}, n=5)$ and not in labour (NIL, $n=9$ ). Comparison of LAB and NIL by Student's t-test. Columns are means and bars are S.E.M.

\section{Discussion}

Four patterns of change in expression of prostanoid receptor genes in the decidua and chorion were observed in this study. The first pattern observed was a decrease in expression of genes encoding receptors which are positively coupled to the phosphatidyl inositol cascade $\left(\mathrm{EP}_{1}\right.$ and $\left.\mathrm{FP}\right)$ in decidua with advancing gestational age (Fig. 5A and B). The parallel decrease in these receptors with advancing gestational age suggests that a prostanoidmediated response acting through the phosphatidyl inositol cascade might inhibit changes in the decidua which promote labour. However, $\mathrm{EP}_{1}$ and $\mathrm{FP}$ receptor activation stimulate myometrial contractility (Senior et al. 1993). Therefore, these data suggest that $\mathrm{EP}_{1}$ and $\mathrm{FP}$ receptormediated effects may stimulate parturition-promoting processes in myometrium and may inhibit parturitionpromoting changes in others.

The second pattern that emerged was a decrease in the expression of a gene which encodes a receptor $\left(\mathrm{EP}_{4}\right)$ which is positively coupled to adenylate cyclase in chorion with advancing gestational age (Fig. 5C). This suggests that an adenylate cyclase-mediated effect may inhibit changes in chorion which promote parturition. This parallels myometrium, where adenylate cyclase-coupled receptors inhibit myometrial contractility (Senior et al. 1993).

The third pattern was a lower level of expression of the gene encoding an adenylate cyclase-coupled receptor $\left(\mathrm{EP}_{2}\right)$ in decidua obtained from animals in spontaneous labour (Fig. 6). This suggests that an adenylate cyclasemediated effect may inhibit parturition-related processes in decidua in cells expressing the $\mathrm{EP}_{2}$ receptor. This parallels decreased $\mathrm{EP}_{2}$ receptor expression in myometrium and cervix (Smith et al. 1999). We hypothesise that reduced expression of this critical receptor may have a key role in promoting parturition in the primate. The absence of any change in expression of the $\mathrm{EP}_{2}$ receptor

\section{A. Decidua}

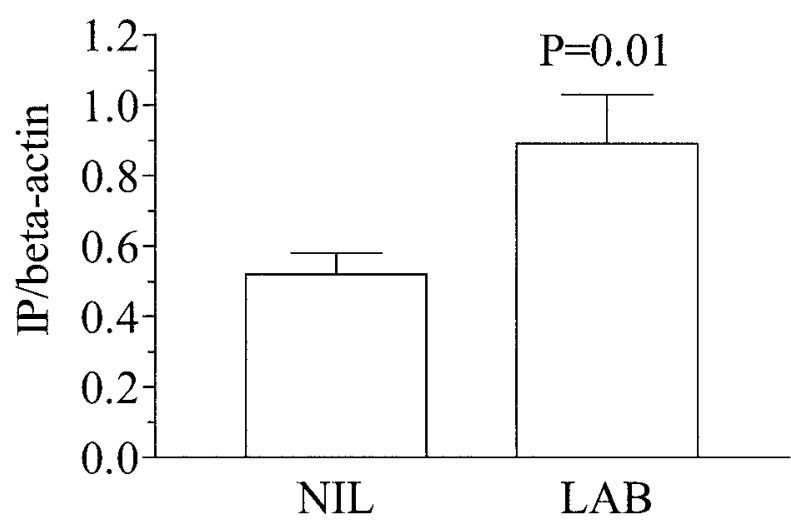

\section{B. Chorion}

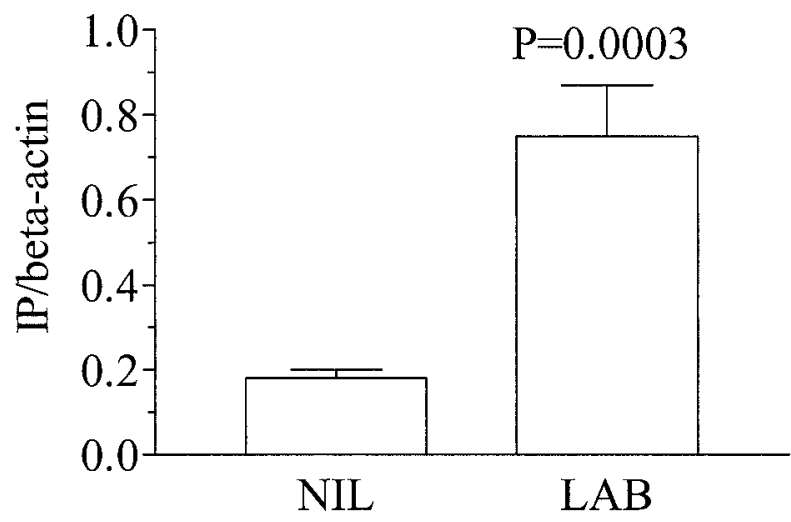

Figure 7 Densitometric analysis of expression of prostanoid receptor IP gene (expressed as a ratio to beta-actin) in labour $(\mathrm{LAB}, n=5)$ and not in labour (NIL, $n=7-9)$ for (A) decidua and (B) chorion. Comparison of LAB and NIL by Student's t-test. Columns are means and bars are S.E.M.

in chorion suggests differential transcriptional control in maternal and fetal intra-uterine tissues.

The fourth pattern, observed in both the decidua and chorion, was an increase in the expression of a gene encoding an adenylate cyclase-coupled receptor (IP) in labour and this was particularly marked in the chorion (Fig. 7A and B). This increased expression suggests that adenylate cyclase activation might promote parturition in cells expressing the IP receptor in these tissues. It was interesting to observe that two adenylate cyclase-coupled prostanoid receptors $\left(\mathrm{EP}_{2}\right.$ and $\left.\mathrm{IP}\right)$ vary in opposite directions in the same tissue in association with labour. This underlines the potential for the same second messenger system to mediate different effects in different cells types 
and this presumably has its basis in different effects of protein kinase A in different cells. Activation of the IP receptor in myometrium inhibits myometrial contractility (Senior et al. 1993) and the observed increase in IP receptor gene expression, like decreased $\mathrm{EP}_{1}$ and $\mathrm{FP}$ expression in decidua with advancing gestational age, suggests dissociation of the roles of receptors in choriodecidua compared with other key tissues. The present findings suggest that extreme caution should be applied in any studies seeking to exploit the IP receptor pathway as a means of uterine tocolysis, since any inhibitory, therapeutic effect on the myometrium may be undermined by effects on the choriodecidua.

The data presented in this study are confined to analysis of mRNA. Ideally, we would have confirmed that message was translated into protein using Western blot analysis and that this is reflected in the presence of receptors using radio-ligand binding. However, antibodies against the currently recognised prostanoid receptors are not available and radio-ligand binding is limited due to the lack of truly specific ligands (Coleman et al. 1990). However, previous studies of key systems involved in parturition have initially focused on mRNA and highlighted physiologically important regulators of the process, such as nitric oxide (Ali et al. 1997) and cyclo-oxygenase-2 (COX-2) (Slater et al. 1999). While our studies on prostanoid receptors in these tissues are, therefore, preliminary, we hypothesize that the observed changes in mRNA may reflect an important role for a direct effect of PGs on the control of the choriodecidua in labour. The pattern sizes of bands observed in the present study in the baboon were very close to those previously described in Northern analysis of human prostanoid receptor gene expression (Hirata et al. 1991, An et al. 1993, Funk et al. 1993, Boie et al. 1994, Lake et al. 1994, Regan et al. 1994, Kotani et al. 1995).

There are relatively few data on prostanoid receptors in the fetal membranes and decidua. A previous study from this laboratory failed to demonstrate variation in either $\mathrm{EP}_{2}$ or $\mathrm{EP}_{4}$ receptor gene expression in labour in ovine endometrium in association with labour (Ma et al. 1999). However, species differences between the sheep and baboon have previously been demonstrated for $\mathrm{EP}_{2}$ receptor-mediated effects on myometrium (Senior et al. 1993, Crankshaw \& Gaspar 1995, Garcia-Villar et al. 1995). A number of studies have postulated a role for prostanoid receptors in the endometrium in association with implantation (Yang et al. 1997). An important role for PGs in this context is supported by the failure of implantation and decidualisation in mice which are null mutant for the COX-2 gene (Lim et al. 1997), and this may be due to the absence of $\mathrm{PGI}_{2}$ (Lim et al. 1999). Other studies have demonstrated expression of the $\mathrm{EP}_{1}$ receptor in amnion WISH cells. Expression of the $\mathrm{EP}_{1}$ receptor in these tissues is stimulated by corticotrophin-releasing hormone (CRH) (Spaziani et al. 2000), interleukin-1 $\beta$
(Spaziani et al. 1999), interleukin-4 (Spaziani et al. 1997) and tumour necrosis factor $\alpha$ (Spaziani et al. 1998). Interestingly, the effect of CRH appeared to be mediated by $\mathrm{PGE}_{2}$ (Spaziani et al. 2000), suggesting the possibility of a feedback loop. However, the data presented in this study are the first, to our knowledge, to demonstrate a changing pattern of prostanoid receptor gene expression with advancing gestational age and in labour.

\section{Acknowledgements}

Financial support was supplied by NIH (HD 21350). G C S S was supported by the Wellcome Trust.

\section{References}

Ali M, Buhimschi I, Chwalisz K \& Garfield RE 1997 Changes in expression of the nitric oxide synthase isoforms in rat uterus and cervix during pregnancy and parturition. Molecular Human Reproduction 3 995-1003.

An S, Yang J, Xia M \& Goetzl EJ 1993 Cloning and expression of the $\mathrm{EP}_{2}$ subtype of human receptors for prostaglandin $\mathrm{E}_{2}$. Biochemical and Biophysical Research Communications 197 263-270.

Boie Y, Rushmore TH, Darmon GA, Grygorczyk R, Slipetz DM, Metters KM \& Abramovitz M 1994 Cloning and expression of a cDNA for the human prostanoid IP receptor. Journal of Biological Chemistry 269 12173-12178.

Casey ML \& MacDonald PC 1988 Biomolecular processes in the initiation of parturition: decidual activation. Clinical Obstetrics and Gynecology 31 533-552.

Challis JRG, Lye SJ \& Gibb W 1997 Prostaglandins and parturition. In The Uterus: Endometrium and Myometrium (Annals of the New York Academy of Sciences), pp 254-267. Ed C Bulletti. New York, NY, USA: New York Academy of Sciences.

Coleman RA, Kennedy I, Humphrey PPA, Bunce K \& Lumley P 1990 Prostanoids and their receptors. In Comprehensive Medicinal Chemistry: The Rational Design, Mechanistic Study and Therapeutic Application of Chemical Compounds, vol. 3, Membranes and Receptors, pp. 643-714. Ed JC Emmett. Oxford, UK: Pergamon Press.

Coleman RA, Smith WL \& Narumiya S 1994 VIII International Union of Pharmacology classification of prostanoid receptors: properties, distribution, and structure of the receptors and their subtypes. Pharmacological Reviews 46 205-229.

Crankshaw DJ \& Gaspar V 1995 Pharmacological characterization in vitro of prostanoid receptors in the myometrium of nonpregnant ewes. Journal of Reproduction and Fertility 103 55-61.

Creasy RK \& Iams JD 1999 Preterm labor and delivery. In MaternalFetal Medicine, pp. 498-531. Eds RK Creasy \& R Resnik. Philadelphia: WB Saunders.

French JI \& McGregor JA 1996 The pathobiology of premature rupture of membranes. Seminars in Perinatology 20 344-368.

Funk CD, Furci L, Fitzgerald GA, Grygorczyk R, Rochette C, Bayne MA, Abramovitz M, Adam M \& Metters KM 1993 Cloning and expression of a cDNA for the human prostaglandin E receptor EP-1 subtype. Journal of Biological Chemistry 268 26767-26772.

Garcia-Villar R, Green LR, Jenkins SL, Wentworth RA, Coleman RA \& Nathanielsz PW 1995 Evidence for the presence of $\mathrm{AH} 13205$-sensitive $\mathrm{EP}_{2}$ prostanoid receptors in the pregnant baboon but not in the pregnant sheep myometrium near term. Journal of the Society for Gynecological Investigation 2 6-12.

Hirata M, Hayashi Y, Ushikubi F, Yokota Y, Kageyamaa R, Nakanishi S \& Narumiya S 1991 Cloning and expression of complementary DNA for a human thromboxane A2 receptor. Nature 349 617-620. 
Kotani M, Tanaka I, Ogawa Y, Usui T, Mori K, Ichikawa A, Narumiya S, Yoshimi T \& Nakao K 1995 Molecular cloning and expression of multiple isoforms of human prostaglandin $\mathrm{E}$ receptor EP-3 subtype generated by alternative messenger RNA splicing: multiple second messenger systems and tissue-specific distributions. Molecular Pharmacology 48 869-879.

Lake S, Gullberg H, Wahlqvist J, Sjogren AM, Kinhult A, Lind P, Hellstrom-Lindahl E \& Stjernschantz J 1994 Cloning of the rat and human prostaglandin F2 alpha receptors and the expression of the rat prostaglandin F2 alpha receptor. FEBS Letters 355 317-325.

Lim H, Paria BC, Das SK, Dinchuk JE, Langenbach R, Trzaskos JM \& Dey SK 1997 Multiple female reproductive failures in cyclooxygenase 2-deficient mice. Cell 91 197-208.

Lim H, Gupta RA, Ma WG, Paria BC, Moller DE, Morrow JD, DuBois RN, Trzaskos JM \& Dey SK 1999 Cyclo-oxygenase-2derived prostacyclin mediates embryo implantation in the mouse via PPARdelta. Genes and Development 13 1561-1574.

Ma XH, Wu WX \& Nathanielsz PW 1999 Differential regulation of prostaglandin $\mathrm{EP}$ and $\mathrm{FP}$ receptors in the pregnant sheep myometrium and endometrium during spontaneous term labor. Biology of Reproduction 61 1281-1286.

Morgan MA, Silavin SL, Wentworth RA, Figueroa JP, Honnebier BO, Fishburne JIJ \& Nathanielsz PW 1992 Different patterns of myometrial activity and 24-h rhythms in myometrial contractility in the gravid baboon during the second half of pregnancy. Biology of Reproduction 46 1158-1164.

Ou CW, Orsino A \& Lye SJ 1997 Expression of connexin-43 and connexin-26 in the rat myometrium during pregnancy and labor is differentially regulated by mechanical and hormonal signals. Endocrinology 138 5398-5407.

Regan JW, Bailey TJ, Pepperl DJ, Pierce KL, Bogardus AM, Donello JE, Fairbairn CE, Kedzie KM, Woodward DF \& Gil DW 1994 Cloning of a novel human prostaglandin receptor with characteristics of the pharmacologically defined EP-2 subtype. Molecular Pharmacology 46 213-220.

Senior J, Marshall K, Sangha R \& Clayton JK 1993 in vitro characterization of prostanoid receptors on human myometrium at term pregnancy. British Journal of Pharmacology 108 501-506.

Slater D, Dennes W, Sawdy R, Allport V \& Bennett P 1999 Expression of cyclo-oxygenase types- 1 and -2 in human fetal membranes throughout pregnancy. Journal of Molecular Endocrinology 22 125-130

Smith GCS, Baguma-Nibasheka M, Wu WX \& Nathanielsz PW 1998 Regional variations in contractile responses to prostaglandins and prostanoid receptor messenger ribonucleic acid in pregnant baboon uterus. American Journal of Obstetrics and Gynecology 179 $1545-1552$.

Smith GCS, Wu WX \& Nathanielsz PW 1999 Baboon labor is associated with decreased uterine prostanoid EP2 receptor expression. Journal of the Society for Gynecological Investigation 6 128A-129A.

Spaziani EP, Tsibris JC, Hunt LT, Benoit RR \& O’Brien WF 1997 The effect of interleukin-1 beta and interleukin-4 on the expression of prostaglandin receptors EP1 and EP3 in amnion WISH cells. American Journal of Reproductive Immunology 38 279-285.

Spaziani EP, Benoit RR, Tsibris JC, Gould SF \& O’Brien WF 1998 Tumor necrosis factor-alpha upregulates the prostaglandin E2 EP1 receptor subtype and the cyclooxygenase-2 isoform in cultured amnion WISH cells. Journal of Interferon and Cytokine Research 18 1039-1044.

Spaziani EP, O’Brien WF, Tsibris JC, Benoit RR \& Gould SF 1999 Modulation of the prostaglandin E receptor: a possible mechanism for infection-induced preterm labor. Obstetrics and Gynecology $\mathbf{9 3}$ 84-88.

Spaziani EP, O'Brien WF, Benoit RR \& Gould SF 2000 Corticotropin-releasing hormone increases the expression of the prostaglandin E(2) receptor subtype EP1 in amnion WISH cells. Biology of Reproduction 62 23-26.

Tabb TN \& Garfield RE 1992 Molecular biology of uterine contractility. Clinical Obstetrics and Gynecology 35 494-504.

Wu WX, Derks JB, Zhang Q \& Nathanielsz PW 1996 Changes in heat shock protein-90 and -70 messenger ribonucleic acid in uterine tissues of the ewe in relation to parturition and regulation by estradiol and progesterone. Endocrinology 137 5685-5693.

Wu WX, Ma XH, Yoshizato T, Shinozuka N \& Nathanielsz PW 1999 Differential expression of myometrial oxytocin receptor and prostaglandin $\mathrm{H}$ synthase 2, but not estrogen receptor alpha and heat shock protein 90 messenger ribonucleic acid in the gravid horn and nongravid horn in sheep during betamethasone-induced labor. Endocrinology 140 5712-5718.

Yang ZM, Das SK, Wang J, Sugimoto Y, Ichikawa A \& Dey SK 1997 Potential sites of prostaglandin actions in the periimplantation mouse uterus: differential expression and regulation of prostaglandin receptor genes. Biology of Reproduction 56 368-379.

Received 12 October 2000

Accepted 18 October 2000 